\title{
A Patient with Suspected Myocarditis Associated with Legionnaires' Disease: A Case Report and Review of the Literature
} Lejyoner Hastası Bir Hastada Miyokardit Şüphesi: Olgu Sunumu ve Literatürün Gözden Geçirilmesi

\author{
Haluk ERDOĞAN1, Halil Olcay ELDEM² \\ ${ }^{1}$ Başkent University Alanya Medical and Research Center, Department of Infectious Diseases and Clinical Microbiology, Alanya, Turkey \\ 2Başkent University Alanya Medical and Research Center, Department of Cardiology, Alanya, Turkey
}

\section{Abstract}

Legionnaires' disease (LD) is a systemic infectious disease caused by Legionella species. It mainly presents with lung involvement. Herein, we present a case with suspected myocarditis associated with LD and review of the relevant literature. An 81-year-old male tourist patient with high fever, cough, imbalance while walking, and confusion presented to the emergency department. The patient was diagnosed with LD based on increased density in the left lower zone on chest x-ray and a positive Legionella urine antigen test. He was administered a combination of claritromycin and levofloxacine on the day of admission. The diagnosis of acute myocarditis was made after worsening of the cardiac functions, ST elevation and troponin I positivity. The patient's symptoms regressed with antibiotic therapy and the patient was transferred to his home country by ambulance plane ten days after admission. A search of PubMed and Web of Science using the keywords "Legionella and myocarditis" revealed 15 case reports, nine of which were in English and were reviewed. There were three female and six male patients with a mean age of 44 years (range: $32-56$ years). Seven were diagnosed with LD by urine antigen testing, one by serological testing and culture, and one by direct fluorescent-antibody staining and culture. Myocarditis was diagnosed by biopsy in two patients and by clinical and laboratory findings in the rest. Myocarditis without existing pneumonia was detected in one case. Electrocardiography abnormalities such as atrial flutter, atrioventricular block, torsade de pointes, sinus tachycardia, QT prolongation, ST elevation, and T wave inversion were detected in seven patients. Ventricle dysfunction on echocardiography and cardiac marker abnormality were detected in all but one of the patients (not tested in one patient). Antimicrobial monotherapy was chosen for three of the cases. One patient died due to myocarditis. In conclusion, myocarditis may develop rarely during the course of LD. Clinical suspicion is essential for the diagnosis. Early diagnosis and appropriate treatment may be life-saving.

Keywords: Pneumonia, Legionella pneumophila, Legionnaires' disease, myocarditis, travel medicine

Lejyoner hastalığı (LH), Legionella bakterisinin etkeni olduğu ve ön planda akciğerlerin tutulduğu sistemik bir enfeksiyon hastalığıdır. Burada LH tanısı alan ve miyokardit şüphesi olan bir olgu sunuldu ve ilgili literatür gözden geçirildi. Seksen bir yaşında turist erkek hasta yüksek ateş, öksürük, yürümede bozukluk ve bilinç değiş̧ikliği şikayeti ile acil servise başvurdu. Akciğer grafisinde sol alt zonda dansite artışı ve idrarda Legionella antijeni olumlu saptanması üzerine LH tanısı aldı. Klaritromisin ve levofloksasin tedavisine yattığı gün başlandı. Kardiyak fonksiyonların kötüleşmesi, ST elavasyonu ve troponin I değerlerinde yükseklik akut miyokardit ile uyumlu bulundu. Antibiyotik tedavisi ile şikayetleri gerileyen hasta kendi isteği üzerine yatışının onuncu günü uçak ambulansla ülkesine gönderildi. PubMed ve Web of Sciences'ta yapılan "Legionella ve miyokardit" taramasında 15 makale bulundu ve İngilizce bildirilen dokuz olgu irdelendi. Hastaların üçü kadın, altısı erkek olup yaş ortalaması 44 yıl (minimum: $32-m a k s i m u m: 56$ yıl) idi. Yedi tanesi idrarda Legionella antijeni, bir tanesi seroloji ve kültür, bir tanesi direkt floresan antikor boyama ve kültür ile LH tanısı almıştır. Miyokardit tanısı iki olguda biyopsi, diğer olgularda ise klinik ve laboratuvar bulgularına göre konmuştur. Bir olguda pnömoni olmadan miyokardit saptanmıştır. Hastaların yedisinde elektrokardiyografide (atrial flatter, atriyoventriküler blok, torsade de pointes, sinüs taşikardisi, QT uzaması, ST elavasyonu, T dalgası inversiyonu) bozukluk saptanmış. Olguların hepsinde ekokardiyografide ventrikül disfonksiyonu ve kardiyak biyomarkırlarda (bir olguda bakılmamış) bozukluk bildirilmiştir. Üç olguda LH'ye karşı antimikrobiyal tedavide monoterapi tercih edilmiştir. Bir hasta hayatını kaybetmiştir. Sonuç olarak LH seyri 
sırasında nadiren de olsa miyokardit gelişebileceği akılda tutulmalıdır. Klinik şüphe tanıda esastır. Lejyoner hastalığının erken tanısı ve uygun tedavisi hayat kurtarıcı olabilir.

Anahtar Kelimeler: Pnömoni, Legionella pneumophila, Lejyoner hastalığı, miyokardit, seyahat tıbbı

\section{Introduction}

Legionnaires' disease (LD) is a systemic infectious disease caused by Legionella bacteria which primarily affects the lungs. More than $90 \%$ of LD is caused by Legionella pneumophila. Legionella bacteria accounts for approximately 2-15\% of communityacquired pneumonia ${ }^{[1,2]}$. In $L D$, involvement of extrapulmonary organs such as heart, liver, kidneys is rare and results from the direct or indirect influence of bacteria (toxins, etc.) ${ }^{[1,3,4]}$. Cardiac involvement in LD may lead to the development of endocarditis, myocarditis, and pericarditis, as well as arrhythmias such as sinus bradycardia, second-and third-degree atrioventricular (AV) block, atrial fibrillation, and premature ventricular contractions. There have also been reports of cases with cardiac involvement in the absence of pulmonary involvement $t^{[5,6]}$. In this paper, we present our management and follow-up of a case of LD with signs of cardiac involvement and review the related literature.

\section{Case Report and Literature Review}

An 81-year-old male patient presented to our emergency department on September 25, 2015 with high fever and cough for four days. The patient exhibited fever with rigors, malaise, gait disorder, and later, altered level of consciousness. According to the patient's history, he was retired, did not smoke, rarely used alcohol, and had a history of coronary artery disease and arterial fibrillation. He was in Turkey as a tourist and was using the water and air conditioning facilities in the hotel. Physical examination revealed moderate general condition with confusion. His vital signs were as follows: body temperature: $39.3{ }^{\circ} \mathrm{C}$, pulse: $102 /$ $\mathrm{min}$, blood pressure: $110 / 80 \mathrm{mmHg}$, respiratory rate: $24 /$ minute, and $\mathrm{SpO}_{2}$ at room temperature: $88 \%$. There were no signs of meningeal irritation. Respiratory system examination revealed rough bilateral inspiratory and expiratory sounds; rales and rhonchi were not observed. The patient's laboratory results at admission were as follows: white blood cell count: $13800 / \mu \mathrm{L}$ (92\% PNL), hemoglobin: $12.6 \mathrm{~g} / \mathrm{dL}$ (13.5-17.5), hematocrit: 36.8\% (40-52), platelet count: $139000 / \mu \mathrm{L}$ (140000-440000), C-reactive protein: $295 \mathrm{mg} / \mathrm{L}(0-5)$, glucose: $149 \mathrm{mg} / \mathrm{L}$ (80-110), blood urea nitrogen: $20 \mathrm{mg} / \mathrm{dL}$ (6-26), creatinine: $1 \mathrm{mg} / \mathrm{dL}$ (0.7-1.3), sodium: $127 \mathrm{meq} / \mathrm{L}$ (132-136), aspartate aminotransferase (AST): $58 \mathrm{U} / \mathrm{L}$ (5-35), alanine aminotransferase (ALT): $41 \mathrm{U} / \mathrm{L}$ (0-55), lactate dehydrogenase: $271 \mathrm{U} / \mathrm{L}$, creatinine kinase (CK): $253 \mathrm{U} / \mathrm{L}(<200)$, CK-MB: 20 U/L (0-24), and troponin I: $40.6 \mathrm{pg} / \mathrm{mL}$ (0-34). Eight hours later, troponin I level was $15.3 \mathrm{pg} / \mathrm{mL}(0-34)$. Increased density was observed in the lower left zone on posteroanterior chest radiography (Figure 1, 2, 3). Legionella urine antigen test was positive (Binax NOW', Legionella urine antigen card, Alero Co, USA) and Streptococcus pneumoniae urine antigen was negative. No growth was observed in the sputum, blood, and urine cultures. Polymerase chain reaction for viruses potentially causing myocarditis was not performed. No pathological findings were observed on brain magnetic resonance (MR). Treatment with intravenous (IV) levofloxacin $750 \mathrm{mg} /$ day and IV clarithromycin $1000 \mathrm{mg} /$ day was initiated. The patient suffered increased respiratory distress (respiratory rate 32 /minute) after seven hours of hospitalization and was transferred to the intensive care unit for oxygen support. During follow-up, he was given nasal oxygen support at two liters/minute. His respiratory distress improved with treatment, the need for oxygen support decreased, and he became agitated in the intensive care unit. As a result, on the following day, he was transferred to inpatient wards.

During consultation with the cardiology department while the patient was in the emergency unit, electrocardiography (ECG) showed sinus tachycardia without ischemic changes. Echocardiography (ECHO) revealed an ejection fraction of $60 \%$, normal wall appearance, and biatrial dilatation. On the $4^{\text {th }}$ day of hospitalization, anterior ST-elevation myocardial infarction pattern (Figure 4) was observed, and akinesia in the apical segments was evident on $\mathrm{ECHO}$. Laboratory values were as follows: ALT: $89 \mathrm{U} / \mathrm{L}$, AST $99 \mathrm{U} / \mathrm{L}, \mathrm{CK}: 288 \mathrm{U} / \mathrm{L}$, and troponin 1: $0.054 \mathrm{ng} / \mathrm{mL}$ (0-0.023). Coronary angiography could not be performed because the patient and his relative did not consent to the procedure.

The patient's agitation resolved on the $5^{\text {th }}$ day of hospitalization and oral antibiotic treatment was initiated on the $7^{\text {th }}$ day. The patient's overall condition improved and his symptoms diminished; on the $10^{\text {th }}$ day of hospitalization, the patient voluntarily returned to his home country by air medical transport. The patient's spouse and doctor reported that the patient continued to be treated for LD in a hospital in his home country and was discharged on October 27, 2015. The patient recovered after undergoing physical therapy rehabilitation and lived in good health for over two years.

\section{Review of Literature}

A literature search of PubMed and Web of Sciences on 1 December 2016 using the keywords "Legionella and myocarditis" yielded 15 articles. The nine cases published in English were analysed and are summarized in Table 1. 


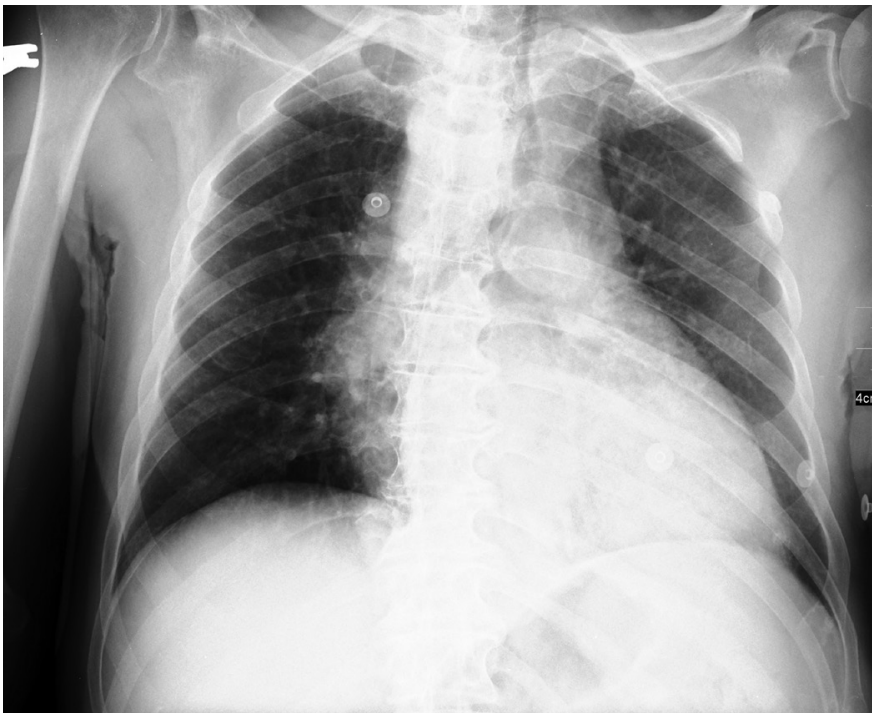

Figure 1. Chest radiograph showing no infiltrates on the day of admission
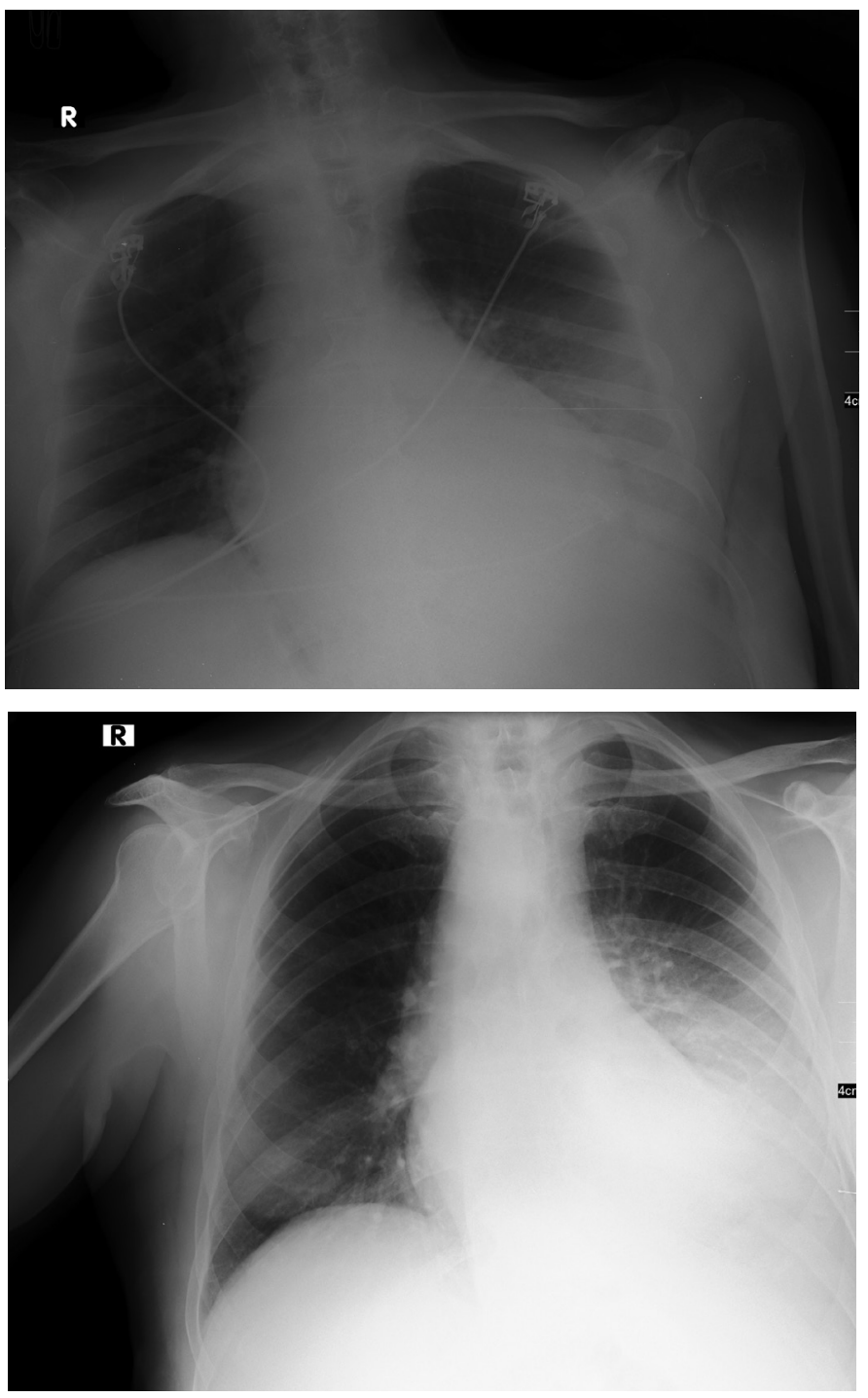

Figure 2,3 . Chest radiograph, two and four days later, showing infiltrates in left lower zone.

\section{Discussion}

The incidence of LD depends on the degree of water reservoir colonization, individual sensitivity, the intensity of contact, and the availability of diagnostic methods able to identify the infection. Cases may be sporadic, or can occur in clusters or epidemics. Legionnaires' disease should be considered in cases of pneumonia with underlying chronic disease, advanced age, smoking habit, history of travel, or extrapulmonary involvement. Elevated liver enzymes, diarrhea, abdominal pain, nausea, relative bradycardia, headache, confusion/lethargy, microscopic hematuria, and elevated CK are more common in LD than in other forms of pneumonia ${ }^{[1,2]}$. In our case, the patient had risk factors, such as advanced age and travel history, as well as extrapulmonary symptoms (gait disorder, altered mental status). Laboratory analyses demonstrated abnormal liver function tests, elevated CK, and hyponatremia. Due to the presence of high fever and altered level of consciousness, the differential diagnosis

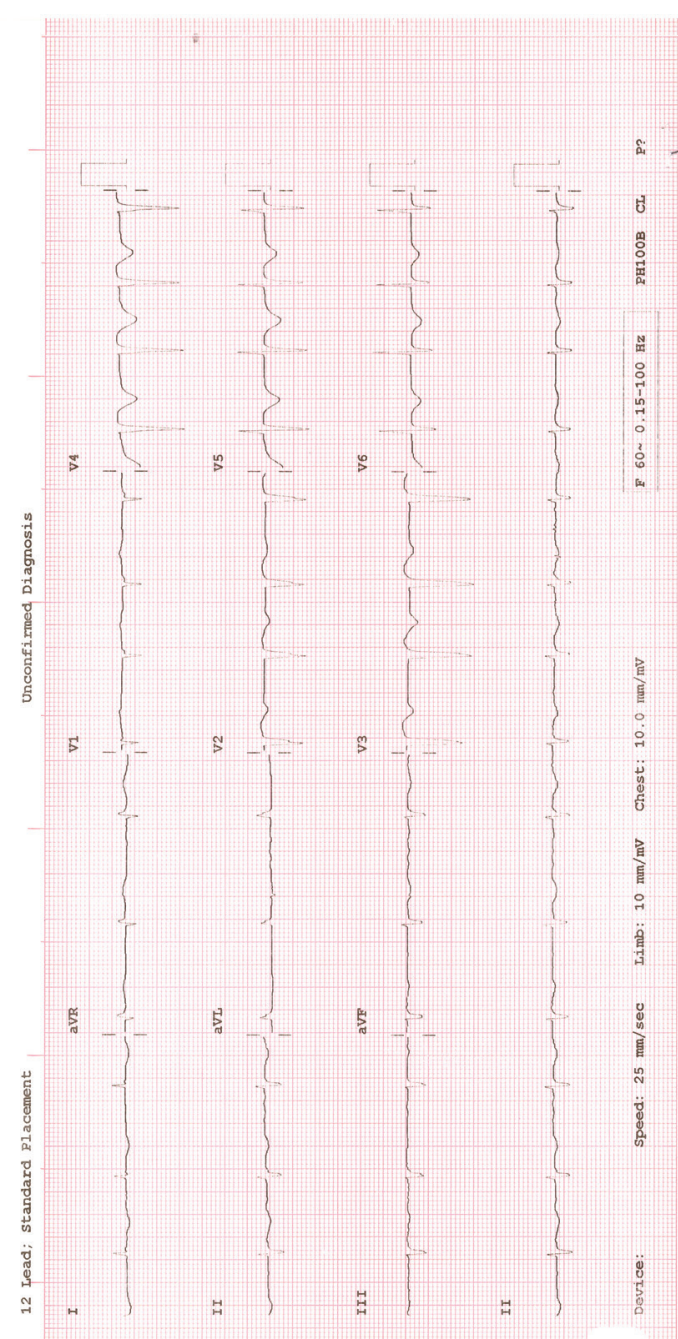

Figure 4. Pathological q waves and minimal ST elevation in leads V1-V3. Diffuse T wave abnormalities in all derivations 
Table 1. Demographic, clinical, and laboratory data of ten patients with Legionnaire's disease and myocarditis

\begin{tabular}{|c|c|c|c|c|c|c|c|c|}
\hline Source & $\begin{array}{l}\text { Age } \\
\text { (years) }\end{array}$ & Sex & $\begin{array}{l}\text { LD } \\
\text { diagnosis }\end{array}$ & ECG & $\mathrm{ECHO}$ & $\begin{array}{l}\text { Cardiac } \\
\text { biomarkers }\end{array}$ & $\begin{array}{l}\text { LD } \\
\text { treatment }\end{array}$ & Outcome \\
\hline Briceño et al. ${ }^{[7]}$ & 48 & $M$ & $\begin{array}{l}\text { Urine } \\
\text { antigen }\end{array}$ & $\begin{array}{l}\text { Atrial flutter with variable } \\
\text { AV block, recuurrent } \\
\text { torsade de pointes, }\end{array}$ & $\begin{array}{l}\text { Dilated cardiomyopathy } \\
\text { with severely depressed } \\
\text { LV systolic function } \\
\text { and severe mitral } \\
\text { regurgitation, LVEF: } \\
20-25 \%\end{array}$ & Positive & $\begin{array}{l}\text { LEV } \\
\text { AZT } \\
\text { DOX }\end{array}$ & Survived \\
\hline Damásio et al. ${ }^{[8]}$ & 39 & $\mathrm{~F}$ & $\begin{array}{l}\text { Urine } \\
\text { antigen }\end{array}$ & No ECG alterations & $\begin{array}{l}\text { No-dilated cardiac } \\
\text { chambers, mild } \\
\text { hypertrophy of the } \\
\text { LV walls, biventricular } \\
\text { dysfunction and mild } \\
\text { circunferential pericardial } \\
\text { effusion. }\end{array}$ & Positive & AZT & Survived \\
\hline Gowani et al. ${ }^{[9]}$ & 41 & M & $\begin{array}{l}\text { Urine } \\
\text { antigen }\end{array}$ & $\begin{array}{l}\text { Sinus tacycardia } \\
\text { Follow-up ECG: Torsade } \\
\text { de pointes, culminating } \\
\text { in an episode of } \\
\text { sustained polymorphic } \\
\text { ventricular tacycardia that } \\
\text { degenerated to ventriculer } \\
\text { fibrillation }\end{array}$ & $\begin{array}{l}\text { Normal LV cavity size; } \\
\text { LVEF } 10-20 \%\end{array}$ & Positive & $\begin{array}{l}\text { AZT } \\
\text { MOX } \\
\text { DOX }\end{array}$ & Survived \\
\hline Ishimaru et al. ${ }^{[10]}$ & 32 & M & $\begin{array}{l}\text { Urine } \\
\text { antigen }\end{array}$ & $\begin{array}{l}\text { Sinus tacycardia with } \\
\text { evidence of left atrial } \\
\text { enlargement and } \mathrm{QT} \\
\text { prolongation } \\
\text { Follow-up ECG: OT } \\
\text { prolongation with } \\
\text { widespread flat T wawes in } \\
\mathrm{V}_{4-6^{\prime}} \text { II, III and } \mathrm{V}_{\mathrm{F}}\end{array}$ & $\begin{array}{l}\text { Diffuse LV dysfunction } \\
\text { encompassing the } \\
\text { coranary artery terriotory } \\
\text { without hypercontractility } \\
\text { of the basal segments. }\end{array}$ & Positive & $\begin{array}{l}\text { ERT } \\
\text { MIN } \\
\text { CLA }\end{array}$ & Survived \\
\hline Burke et al. ${ }^{[11]}$ & 50 & $\mathrm{~F}$ & $\begin{array}{l}\text { Urine } \\
\text { antigen }\end{array}$ & $\begin{array}{l}\text { ST segment elevation in } \\
\text { the anterolateral leads. }\end{array}$ & $\begin{array}{l}\text { Normal LV size and } \\
\text { function and mild } \\
\text { pericardial effusion. Five } \\
\text { days later, moderate } \\
\text { global systolic impairment } \\
\text { in LV function, LVEF: 35\%. }\end{array}$ & Positive & MOX & Survived \\
\hline $\begin{array}{l}\text { Antonarakis et } \\
\text { al. }{ }^{[12]}\end{array}$ & 45 & M & $\begin{array}{l}\text { Urine } \\
\text { antigen }\end{array}$ & $\begin{array}{l}\text { Sinus tacycardia without } \\
\text { evidence of iscemic } \\
\text { changes } \\
\text { Follow-up ECG: T-wave } \\
\text { inversions in the } \\
\text { anterolateral leads }\end{array}$ & $\begin{array}{l}\text { Diffuse LV sytolic } \\
\text { dysfunction with global } \\
\text { myocardial hypokinesis, } \\
\text { LVEF: } 15-20 \% \text {. }\end{array}$ & Positive & LEV & Survived \\
\hline Bodur et al. ${ }^{[13]}$ & 43 & M & $\begin{array}{l}\text { Urine } \\
\text { antigen }\end{array}$ & - & LVEF 55-60\% & - & $\begin{array}{l}\text { LEV } \\
\text { CLA } \\
\text { RIF }\end{array}$ & Survived \\
\hline $\begin{array}{l}\text { De Lassence et } \\
\text { al. } .^{[14]}\end{array}$ & 56 & $\mathrm{~F}$ & $\begin{array}{l}\text { DFA and } \\
\text { culture }\end{array}$ & Sinus tacycardia & $\begin{array}{l}\text { LV was not dilated ( } 57 \\
\mathrm{~cm} 3 / \mathrm{m} 2), \text { LVEF } 46 \% \text {, no } \\
\text { regional abnormal wall } \\
\text { motion or wall thickening }\end{array}$ & Positive & $\begin{array}{l}\text { PEF } \\
\text { ERT }\end{array}$ & Ex \\
\hline $\begin{array}{l}\text { Armengol et } \\
\text { al. }{ }^{[15]}\end{array}$ & 43 & M & $\begin{array}{l}\text { Serology } \\
\text { and } \\
\text { culture }\end{array}$ & $\begin{array}{l}\text { Sinus tachycardia } \\
\text { Follow-up ECG: Sinus } \\
\text { tachycardia with a left } \\
\text { bundle branch block }\end{array}$ & Decreased LV function & Positive & ERT & Survived \\
\hline $\begin{array}{l}\text { Erdoğan et al. } \\
\text { (present case) }\end{array}$ & 81 & M & $\begin{array}{l}\text { Urine } \\
\text { antigen }\end{array}$ & $\begin{array}{l}\text { Patholocigal q waves and } \\
\text { minimal ST elavation in } \\
\text { leads V1-V3. Diffuse T } \\
\text { wave abnormalities in all } \\
\text { derivations }\end{array}$ & $\begin{array}{l}\text { Akinesia in the apical } \\
\text { segments of the LV }\end{array}$ & Positive & $\begin{array}{l}\text { LEV } \\
\text { CLA }\end{array}$ & Survived \\
\hline
\end{tabular}

LD: Legionnaire's disease, ECG: Electrocardiography, ECHO: Echocardiography, AV: Atrioventricular, DFA: Direct fluorescent antibody staining, F: Female, M: Male, AZT: Azithromycin, CLA: Clarithromycin, ERT: Erythromycin, DOX: Doxycycline, LEV: Levofloxacin, MIN: Minocycline, MOX: Moxifloxacin, PEF: Pefloxacin, RIF: Rifampicin LV: Left ventricular, LVEF: Left ventricular ejection fraction 
included acute central nervous system infections and central vascular events. However, lack of any findings of meningeal irritation or signs of pathology on cranial MR were unsupportive of these prediagnosis.

Criteria for definitive diagnosis of LD are isolation of Legionella bacteria in cultures, positive Legionella urine antigen test, and observing at least a 4-fold increase in antibody titer against $L$. pneumophila serogroup 1 in paired serology. The Legionella urine antigen test is valuable in LD diagnosis because patients become positive within the first few days of infection; it is not affected by antibiotic use, is easily performed, and provides rapid results. The test has a sensitivity of $70-80 \%$ and specificity close to $100 \%$; the sensitivity and specificity rates of the urinary card test are comparable to those of ELISA. The biggest disadvantage of the test is the lack of reliability for species and serogroups other than L. pneumophila serogroup $1^{[1,2]}$. Definitive LD diagnosis was established for our patient upon obtaining a positive Legionella urine antigen result. Legionella bacteria could not be isolated in the sputum culture obtained when the patient was receiving antibiotic treatment. Serologic tests were not used in our case because of their limited benefit in early diagnosis.

Myocarditis is an inflammatory disease of the cardiac muscle which may exhibit different clinical presentations depending on the severity of cardiac involvement (focal, diffused, etc.). It may show wide clinical variability, ranging from mild symptoms to heart failure, cardiogenic shock, arrhythmia, and sudden death. ECHO findings can range from diffused wall motion abnormalities to regional motion abnormalities. Clinical suspicion is essential for the diagnosis of myocarditis. Elevated cardiac biomarkers (such as troponin, CK-MB), ECG changes indicating acute myocardial damage, arrhythmia, and new and unexplained disruptions of cardiac function are also suggestive of myocarditis ${ }^{[16]}$. Endomyocardial biopsy is the gold standard in diagnosis, but it must be noted that this technique is applicable only in selected cases due to the difficulty and the risk involved.

Of the nine cases identified in our literature review, the male:female ratio was 2:1 and the mean age was 44 years (range: 32-56 years). Seven of the cases exhibited abnormalities on ECG (atrial flutter, AV block, torsade de pointes, sinus tachycardia, prolonged OT, ST elevation, T-wave inversion), and all cases showed ventricular dysfunction on ECHO. Cardiac biomarker abnormalities were reported in eight of the cases. In only two cases, the myocarditis diagnosis was based on cardiac biopsy. In our case, clinical findings were accompanied by elevated troponin I values, newly emergent ST elevation, and akinesia in apical segments on ECHO. Cardiac biopsy was not performed. When observed only in the apical myocardial segments, as in our case, wall motion abnormalities may be indicative of focal myocarditis. ECG abnormalities associated with myocarditis may initially mimic ST-elevation or non-ST-elevation acute myocardial infarction ${ }^{[17]}$. However, considering how ST-T abnormalities evolve in the course of time, the ECG changes associated with acute myocarditis evolve much slower than those seen with acute myocardial infarction ${ }^{[18]}$. As in our case, persistence for even a few days without forming pathological $\mathrm{Q}$ wave is indicative of acute myocarditis. In cases with ECG and ECHO findings and elevated cardiac biomarkers, stress cardiomyopathy or neurogenic heart syndrome should also be considered in the differential diagnosis. Stress cardiomyopathy is a condition that occurs in patients under severe physical or psychic stress. Findings include apical aneurysm, as well as ECG changes mimicking acute myocardial infarction and cardiac enzyme abnormalities ${ }^{[19]}$. In our case, the confirmed presence of an etiology (LD) that may cause may cause myocarditis, increased the probability of myocarditis. However, the likelihood of the two conditions co-occurring is even higher.

Combination therapy is usually preferred in cases with severe LD and extrapulmonary organ involvement. Macrolides are administered with rifampicin or a quinolone drug as combination therapy. The duration of treatment is 7-10 days. Treatment should be extended to 14-21 days for cases with severe course, extrapulmonary organ involvement, and immunosuppression ${ }^{[1,2]}$. It should be kept in mind that macrolides and quinolones used in the specific treatment of LD may have an arrhythmogenic effect or exacerbate an underlying condition. We preferred a combination of quinolone and macrolide for our patient. Six of the nine cases found in our literature review were also treated with combination antibiotic therapy. Even under appropriate antibiotic therapy, a patient's clinical condition may deteriorate or increased density may be observed on chest radiography, as in our case. In a case reported by Briceño et al. ${ }^{[7]}$, the patient developed severe left ventricular failure and cardiogenic shock due to repolarization anomaly despite receiving appropriate antibiotic therapy. A mechanical assist device (TandemHeart pVAD) was used briefly to treat cardiogenic shock. Damásio et al. ${ }^{[8]}$ used intra-aortic balloon pump and extracorporeal membrane oxygenation in a patient who developed cardiogenic shock. Only one of the nine cases did not respond to treatment and died.

In conclusion, LD should be suspected in cases of severe community-acquired pneumonia with prominent extrapulmonary symptoms. It is important to be aware that symptoms and findings related to cardiac involvement may be encountered during the clinical course of LD. Clinical suspicion is essential for diagnosis. Early diagnosis and proper treatment of LD may be life-saving.

\section{Ethics}

Informed Consent: Consent form was filled out by patient relative. 
Peer-review: Externally and internally peer-reviewed.

\section{Authorship Contributions}

Surgical and Medical Practices: H.E., H.O.E, Concept: H.E., H.O.E, Design: H.E., H.O.E, Data Collection or Processing: H.E., H.O.E, Analysis or Interpretation: H.E., H.O.E, Literature Search: H.E., H.O.E, Writing: H.E.

Conflict of Interest: No conflict of interest was declared by the authors.

Financial Disclosure: The authors declared that this study received no financial support.

\section{References}

1. Phin N, Parry-Ford F, Harrison T, Stagg HR, Zhang N, Kumar K, Lortholary O, Zumla A, Abubakar I. Epidemiology and clinical management of Legionnaires' disease. Lancet Infect Dis. 2014;14:1011-21.

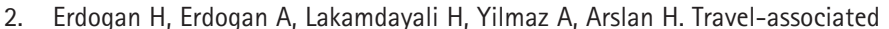
Legionnaires disease: clinical features of 17 cases and a review of the literature. Diagn Microbiol Infect Dis. 2010;68:297-303.

3. Rihs JD, Yu VL, Zuravleff JJ, Goetz A, Muder RR. Isolation of Legionella pneumophila from blood with the BACTEC system: a prospective study yielding positive results. J Clin Microbiol. 1985;22:422-4.

4. Evans $\mathrm{CP}$, Winn WC Jr. Extrathoracic localization of Legionella pneumophila in Legionnaires' pneumonia. Am J Clin Pathol. 1981;76:813-5.

5. Gross D, Willens $H$, Zeldis SM. Myocarditis in legionnaires' disease. Chest. $1981 ; 79: 232-4$

6. Castellani Pastoris M, Nigro G, Midulla M. Arrhythmia or myocarditis: a novel clinical form of Legionella pneumophila infection in children without pneumonia. Eur J Pediatr. 1985;144:157-9.

7. Briceño DF, Fernando RR, Nathan S, Loyalka P, Kar B, Gregoric ID. Tandem heart as a bridge to recovery in Legionella myocarditis. Tex Heart Inst J. 2015:42:357-61.
8. Damásio AF, Rodrigues L, Miranda L, Coelho P, Banazol N, Colaço J, Fragata J. Fulminant myocarditis caused by Legionella pneumophila: case report. Rev Port Cardiol. 2014;33:185.e1-5.

9. Gowani SA, Kumar A, Arora S, Lahiri B. Legionella pneumonia complicated by myocarditis and torsades de pointes: A case report and review of literature. Conn Med. 2013;77:331-4.

10. Ishimaru N, Suzuki H, Tokuda Y, Takano T. Severe Legionnaires' disease with pneumonia and biopsy-confirmed myocarditis most likely caused by Legionella pneumophila serogroup 6. Intern Med. 2012;51:3207-12.

11. Burke PT, Shah R, Thabolingam R, Saba S. Suspected Legionella-induced perimyocarditis in an adult in the absence of pneumonia: a rare clinical entity. Tex Heart Inst J. 2009;36:601-3.

12. Antonarakis ES, Wung PK, Durand DJ, Leyngold I, Meyerson DA. An atypical complication of atypical pneumonia. Am J Med. 2006;119:824-7.

13. Bodur H, Savran Y, Koca U, Kilinç O, Albayrak S, Itil O, Akoglu S. Legionella pneumonia with acute respiratory distress syndrome, myocarditis and septic shock successfully treated with Drotrecogin Alpha (activated). Eur J Anaesthesiol. 2006;23:808-10.

14. De Lassence A, Matsiota-Bernard P, Valtier B, Franc B, Jardin F, Nauciel C A case of myocarditis associated with Legionnaires' disease. Clin Infect Dis. 1994;18:120-1.

15. Armengol S, Domingo C, Mesalles E. Myocarditis: a rare complication during Legionella infection. Int J Cardiol. 1992;37:418-20.

16. Sinagra G, Anzini M, Pereira NL, Bussani R, Finocchiaro G, Bartunek J, Merlo M. Myocarditis in Clinical Practice. Mayo Clin Proc. 2016;91:1256-66.

17. Nisbet BC, Breyer M. Acute myopericarditis with focal ECG findings mimicking acute myocardial infarction. J Emerg Med. 2010;39:e153-8.

18. Nable JV, Brady W. The evolution of electrocardiographic changes in STsegment elevation myocardial infarction. Am J Emerg Med. 2009;27:734-46.

19. Tsuchihashi $K$, Ueshima $K$, Uchida $T$, Oh-mura $N$, Kimura $K, O$ wa $M$, Yoshiyama M, Miyazaki S, Haze K, Ogawa H, Honda T, Hase M, Kai R, Morii I; Angina pectoris-myocardial infarction investigations in Japan. Transient left ventricular apical ballooning without coronary artery stenosis: a novel heart syndrome mimicking acute myocardial infarction. Angina Pectoris-Myocardial Infarction Investigations in Japan. J Am Coll Cardiol. 2001;38:11-8 